\title{
Puan

\section{PELATIHAN PENGGUNAAN STRATEGI MEMBACA BAGI SISWA KELAS IX SMP NEGERI 4 KOTA SOLOK TAHUN AKADEMIK 2019/2020 DALAM MENJAWAB SOAL UJIAN NASIONAL BAHASA INGGRIS}

\author{
Fitri Handayani \\ Universitas Mahaputra Muhammad Yamin, Solok, Indonesia \\ e-mail: fhandayani1786@gmail.com \\ Marsika Sepyanda \\ Universitas Mahaputra Muhammad Yamin, Solok, Indonesia \\ e-mail: marsikayanda@gmail.com \\ Risza Dwiputri \\ Universitas Mahaputra Muhammad Yamin, Solok, Indonesia \\ e-mail: risza.dwiputri@gmail.com \\ Zulfariati \\ Universitas Mahaputra Muhammad Yamin, Solok, Indonesia \\ e-mail: zulfariatijun@gmail.com
}

\begin{abstract}
The readiness of grade IX students of SMP in facing the national exam was still not optimal. It can be seen from the obstacles encountered by the students related to the amount of material being studied and the limited time available at school. Furthermore, the students were also still unfamiliar with the UN questions tested due to the lack of practice in discussing UN questions. This problem can be overcome by providing training to students on the use of reading strategies to be applied in answering English UN questions. The participants of this service program were grade IX students of SMP Negeri 4 Solok in the 2019/2020 academic year who will take the national exam. The use of reading strategies is an approach to understand English texts that can be used in solving English UN questions. The steps of implementing this service program were carried out through several stages, namely (1) giving try out to assess students' ability to answer UN questions, (2) giving guidance and training in using reading strategies in answering UN questions, and (3) giving final try out as evaluation of the implementation of community service activities. After implementing the steps above, it showed that students had broad insights on strategies to solve English National Examination questions. Students also became more enthusiastic and active in answering English UN questions. Besides that, students also got information that is very useful in preparing themselves as early as possible to face the national exam. Given the large benefits of community service activities, it is necessary to provide intensive and structured training for grade IX students of SMP on tips and tricks for answering English UN questions easily.
\end{abstract}

Keywords - English subject, National examination, Reading strategies. 


\section{PENDAHULUAN}

Dalam pendidikan, salah satu bukti keberhasilan dalam proses pembelajaran adalah dengan pencapaian hasil ujian yang diperoleh. Hasil ujian siswa akan menentukan tercapainya tujuan pembelajaran atau tidak. Pencapaian hasil ujian ini didapatkan melalui evaluasi pada proses pendidikan yang sudah dijalankan. Secara umum, evaluasi adalah serangkaian kegiatan yang ditujukan untuk meningkatkan mutu dan kapasitas dari suatu institusi dalam menjalankan programnya. Dalam pendidikan, evaluasi adalah kegiatan pengumpulan informasi yang ditujukan untuk melihat capaian belajar kelas atau kelompok (Djemari Mardapi, 2008). Dengan adanya evaluasi ini akan memberikan data dan laporan berkaitan dengan pencapaian yang telah diperoleh dan yang belum diperoleh secara maksimal, sehingga, memotivasi pendidik dan peserta didik untuk mengajar dan belajar dengan lebih baik.

Salah satu bentuk evaluasi dalam bidang pendidikan adalah ujian nasional. Ujian nasional merupakan bentuk penilaian terhadap proses belajar siswa yang telah menempuh pendidikan dan pembelajaran di sekolah. Ujian nasional yang selanjutnya disingkat UN adalah kegiatan pengukuran capaian kompetensi lulusan pada mata pelajaran tertentu secara nasional dengan mengacu pada Standar Kompetensi Lulusan (Pasal 1 Peraturan Menteri Pendidikan dan Kebudayaan Republik Indonesia Nomor 4 tahun 2018 Tentang Penilaian Hasil Belajar oleh Satuan Pendidikan dan Penilaian Hasil Belajar oleh Pemerintah). Selanjutnya, di dalam pasal ini juga disebutkan bahwa hasil UN ini akan digunakan sebagai dasar untuk pemetaan mutu program dan/atau Satuan Pendidikan; pertimbangan seleksi masuk Jenjang Pendidikan berikutnya; dan pembinaan dan pemberian bantuan kepada Satuan Pendidikan dalam upayanya untuk meningkatkan mutu pendidikan. Sehingga, UN berfungsi sebagai alat pengendalian dan peningkatan mutu pendidikan secara nasional, komponen penentu kelulusan peserta didik, dan salah satu aspek yang dipertimbangkan dalam seleksi penerimaan pada jenjang pendidikan yang lebih tinggi (Hafis, 2018). Sejalan dengan hal tersebut, Mardapi (2009) juga menyatakan bahwa ujian nasional memberikan standar yang mudah untuk melakukan pemantauan mutu yang akan menggerakkan guru dan siswa untuk mengajar dan belajar secara maksimal selama proses pembelajaran.

Pada jenjang SMP/MTs, salah satu mata pelajaran yang diujikan dalam UN adalah bahasa Inggris. Dalam mata pelajaran ini, siswa harus menjawab 50 butir soal dengan materi tentang jenis teks-teks transaksional/interpersonal tertulis (a.l. meminta maaf, harapan, doa, maksud, kebiasaan, keharusan), Fungsional pendek (a.l. announcement, notice, label), dan Descriptive, recount, narrative, procedure, report (Kisi-Kisi Ujian Nasional Sekolah Menengah Pertama/Madrasah Tsanawiyah Tahun Pelajaran 2018/2019).

Namun pada kenyataannya, tidak semua siswa bisa menguasai materi yang diujikan dengan baik. Hal ini didukung dari capaian nasional hasil UN bahasa Inggris SMP tahun 2019 dari Pusat Penilaian Pendidikan Kementrian Pendidikan dan Kebudayaan menunjukan bahwa capaian rata-rata nilai UN bahasa Inggris SMP adalah $50.23 \%$. Ini mengindikasikan bahwa kemampuan siswa dalam menjawab soal UN dan menguasai materi yang diujikan dalam UN masih tergolong rendah. 
Permasalahan tentang rendahnya penguasaan bahasa Inggris dalam menghadapi UN juga dialami oleh siswa SMP Negeri 4 Kota Solok. melalui hasil survei dan wawancara dengan siswa SMP Negeri 4 Solok diperoleh informasi bahwa dalam rangka menghadapi ujian nasional Tahun 2020 ini, siswa belum banyak latihan dalam pembahasan soal khususnya soal-soal mata pelajaran bahasa Inggris. Terbatasnya waktu belajar disekolah serta banyaknya materi yang harus dipelajari membuat mereka belum siap dalam menghadapi ujian nasional. Kondisi ini juga dikuatkan oleh informasi dari guru mata pelajaran, diketahui bahwa waktu untuk proses pembelajaran di sekolah sangat singkat sedangkan materi pelajaran sangat padat. Oleh karena itu, guru lebih fokus untuk mengejarkan materi pelajaran. Akibatnya waktu untuk mempersiapkan siswa menghadapi ujian nasional sangat terbatas.

Disamping itu, siswa masih menemukan kesulitan dalam menjawab soal-soal UN bahasa Inggris dikarenakan kemampuan yang masih rendah dalam penguasaan bahasa Inggris. Berdasarkan hasil wawancara dengan siswa SMP N 4 kota Solok, ada beberapa kendala yang mereka hadapi dalam menjawab latihan-latihan soal UN. Pertama, terbatasnya penguasaan kosakata bahasa Inggris membuat siswa sukar memahami soal dan menentukan jawabannya. Selanjutnya, mereka juga menghadapi kesulitan dalam menjawab soal teks bacaan yang terlalu panjang dan mereka tidak memiliki strategi membaca yang tepat dalam menghadapi ini. Sehingga, mereka menghabiskan banyak waktu hanya untuk mencerna isi teks dan kurang maksimal dalam menjawab soal yang ada karena waktu telah banyak dihabiskan untuk membaca teks. Kendala lain yang dihadapi siswa adalah tidak memahami struktur teks yang ditanyakan dalam soal. Sehingga, mereka kesulitan dalam menentukan main ideas, purpose, atau conclusion dalam bacaan.

Salah satu cara yang dapat diberikan untuk membantu siswa dalam menyelesaikan soal-soal bahasa Inggris UN adalah dengan melatih siswa dan memberikan tips serta trik dalam mengerjakan soal-soal yang panjang dan berupa teks tersebut melalui penerapan strategi membaca. Oleh karena itu, tim pengabdian program studi pendidikan bahasa Inggris Universitas Mahaputra Muhammad Yamin menawarkan solusi untuk melaksanakan bimbingan dan pelatihan dalam pembahasan soal-soal ujian nasional bahasa Inggris sebanyak 2 kali pertemuan dan diakhiri dengan kegiatan try out ujian nasional. Kegiatan ini diperuntukkan bagi siswa kelas IX. Kegiatan pembahasan soal ini diharapkan dapat melatih siswa untuk terbiasa menjawab soal-soal yang berhubungan dengan materi ujian nasional bahasa Inggris.

Solusi yang kami tawarkan dapat memberikan manfaat diantaranya: (1) membiasakan siswa dalam menjawab soal yang akan menjadi bahan dalam ujian nasional mata pelajaran bahasa Inggris, (2) menambah pemahaman siswa terhadap materi-materi yang diujikan dan menambah penguasaan materi pembelajaran sebagai bekal melanjutkan pendidikan ke tingkat SMA atau SMK.

\section{METODE}

Kegiatan pengabdian kepada masyarakat ini dilaksanakan oleh program studi pendidikan bahasa Inggris Universitas Mahaputra Muhammad Yamin Solok terhadap siswa kelas IX SMP Negeri 4 Kota Solok tahun akademik 2019/2020. SMP 
Negeri Kota 4 Solok berdiri sejak 02 Maret 1979 terletak di Jalan Syekh Ibrahim no. 96, Kelurahan Sinapa Piliang, Kecamatan Lubuk Sikarah, Kota Solok. SMP Negeri 4 Kota Solok berjarak $1 \mathrm{~km}$ dari Kampus 1, Universitas Mahaputra Muhammad Yamin Solok, \pm 13 menit perjalanan dengan menggunakan mobil atau sepeda motor. Data jumlah siswa kelas IX Tahun Ajaran 2019/2020 dapat dijabarkan pada tabel berikut ini:

Tabel 1 Data Jumlah Siswa Kelas IX SMP Negeri 4 Kota Solok

\begin{tabular}{|c|l|c|}
\hline No & \multicolumn{1}{|c|}{ Kelas } & Jumlah Siswa \\
\hline 1 & IX .1 & 28 \\
\hline 2 & IX .2 & 28 \\
\hline 3 & IX .3 & 27 \\
\hline 4 & IX .4 & 27 \\
\hline 5 & IX .5 & 27 \\
\hline 6 & IX .6 & $\mathbf{1 6 3}$ \\
\hline & Jumlah & \\
\hline
\end{tabular}

Kegiatan pengabdian dimulai dengan pemberian try out ujian nasional untuk menilai kemampuan siswa dalam menjawab soal-soal UN. Dari hasil try out didapatkan bahwa masih banyak siswa yang belum bisa menjawab soal UN dengan benar. Hal ini diketahui dari banyaknya jawaban yang salah dalam tes yang mereka lakukan. Secara umum, siswa masih belum bisa menjawab soal yang berkaitan dengan teks bacaan seperti mengidentifikasi ide pokok dalam teks, menemukan informasi yang ditanyakan dalam teks, serta memahami isi struktur teks secara keseluruhan. Disamping itu beberapa siswa juga masih belum paham tentang soal yang berkaitan dengan unsur kebahasaan seperti mencari rujukan kata ganti (reference), sinonim/antonim kata, dan word order.

Berdasarkan analisis try out tersebut, tim merumuskan materi pengabdian yang berfokus kepada penggunaan strategi membaca yang aplikatif terhadap peningkatan kemampuan siswa dalam menjawab soal UN. Strategi membaca merupakan salah satu keterampilan yang harus dikuasai siswa dalam mengerjakan soal-soal UN karena dengan penerapan strategi tersebut siswa dapat menjawab pertanyaan bacaan dengan tepat dan akurat. Dalam kegiatan pengabdian ini ada 5 strategi membaca yang diaplikasikan dalam menjawab soal-soal UN bahasa Inggris SMP yang meliputi skimming, scanning, recognizing text-organization,dan interpreting reference. Selanjutnya, siswa dibimbing secara aktif untuk menyelesaikan soal UN bahasa Inggris dengan mengaplikasikan secara langsung strategi membaca yang meliputi skimming, scanning, recognizing text-organization, 
dan interpreting reference. Pelatihan penggunaan strategi membaca ini dilaksanakan selama dua kali pertemuan bagi masing-masing kelas. Di akhir pertemuan, siswa kembali diberikan try out sebagai evaluasi terhadap kegiatan pengabdian.

Kegiatan pengabdian pada masyarakat ini dilaksanakan dari tanggal 6 November 2019 - 7 Januari 2020 yang diikuti oleh 163 orang siswa SMP Negeri 4 Kota Solok. Jadwal kegiatan pengabdian dapat dilihat pada tabel dibawah ini.

Tabel 2 Jadwal Pelaksanaan Pengabdian SMP Negeri 4 Solok

\begin{tabular}{|c|c|c|c|c|c|c|}
\hline Tgl & IX.A & IX.B & IX.C & IX.D & IX.E & IX.F \\
\hline $\begin{array}{c}6 \\
\text { NOV } \\
2019\end{array}$ & $\begin{array}{l}\text { Try Out } \\
\text { B.Ing }\end{array}$ & $\begin{array}{c}\text { Try Out } \\
\text { B.Ing }\end{array}$ & $\begin{array}{c}\text { Try Out } \\
\text { B.Ing }\end{array}$ & $\begin{array}{l}\text { Try Out } \\
\text { B.Ing }\end{array}$ & $\begin{array}{c}\text { Try Out } \\
\text { B.Ing }\end{array}$ & $\begin{array}{c}\text { Try Out } \\
\text { B.Ing }\end{array}$ \\
\hline $\begin{array}{c}16 \\
\mathrm{NOV}\end{array}$ & & & B.Ing & & & \\
\hline 2019 & & B.Ing & & & & B.Ing \\
\hline $\begin{array}{c}23 \\
\text { NOV }\end{array}$ & & & B.Ing & & & \\
\hline 2019 & & B.Ing & & & & B.Ing \\
\hline $\begin{array}{c}30 \\
\text { NOV }\end{array}$ & B.Ing & & & & B.Ing & \\
\hline 2019 & & & & B.Ing & & \\
\hline $\begin{array}{c}7 \\
\text { DES }\end{array}$ & B.Ing & & & & B.Ing & \\
\hline 2019 & & & & B.Ing & & \\
\hline $\begin{array}{c}7 \\
\text { JAN } \\
2020\end{array}$ & $\begin{array}{l}\text { Try Out } \\
\text { B.Ing }\end{array}$ & $\begin{array}{l}\text { Try Out } \\
\text { B.Ing }\end{array}$ & $\begin{array}{c}\text { Try Out } \\
\text { B.Ing }\end{array}$ & $\begin{array}{c}\text { Try Out } \\
\text { B.Ing }\end{array}$ & $\begin{array}{c}\text { Try Out } \\
\text { B.Ing }\end{array}$ & $\begin{array}{c}\text { Try Out } \\
\text { B.Ing }\end{array}$ \\
\hline
\end{tabular}

\section{HASIL DAN PEMBAHASAN}

Pelatihan penggunaan strategi membaca dalam menjawab soal UN bahasa Inggris bagi siswa SMP N 4 Kota Solok disambut baik oleh peserta pengabdian. Selama pelatihan ini, semua siswa tampak antusias dan tekun mengikuti pembahasan soal ujian nasional sampai akhir. Kondisi ini tergambar dari tidak adanya siswa yang lalu lalang dan ribut selama pembahasan berlangsung. Disamping itu, siswa juga antusias dalam mengerjakan soal, bertanya dan menanggapi setiap pertanyaan dosen. Antusiasme siswa ini tidak terlepas dari cara 
penyajian dari tim yang memberikan penjelasan kepada siswa dengan bahasa yang sederhana dan mudah diserap.

Selain itu, dengan adanya kegiatan pelatihan pembahasan soal-soal UN ini memberi perubahan terhadap peningkatan keterampilan siswa dalam menyelesaikan soal-soal UN bahasa Inggris. Siswa sudah mulai tahu dan familiar dengan tipe-tipe soal yang diujikan dalam UN. Mereka juga memiliki pengetahuan tentang strategi membaca yang dapat digunakan dalam menjawab soal tersebut sehingga mereka sudah mulai siap dalam menghadapi ujian nasional. Peningkatan kemampuan tersebut juga bisa digambarkan dari hasil try out ujian nasional bahasa Inggris sebelum dan sesudah pelatihan. Meskipun belum begitu signifikan, tapi peningkatan ini menununjukkan nilai postif bahwa pada dasarnya siswa bisa dipersiapkan dengan baik sebelum menghadapi UN dengan pemberian latihan yang intensif. Hasil peningkatan kemampuan siswa dalam menjawab soal UN sebelum dan setelah pelatihan dapat dilihat pada grafik dibawah ini.

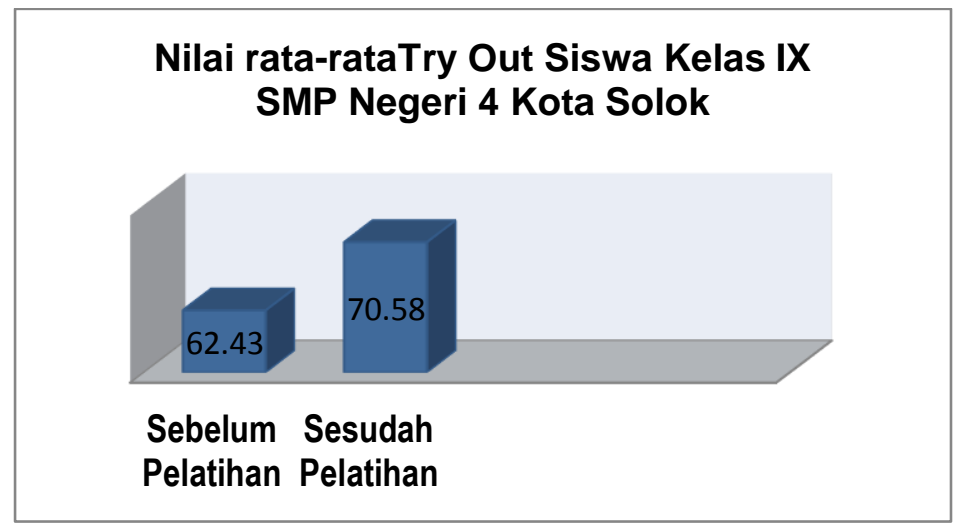

Gambar 1 Grafik Nilai

Berdasarkan hasil rata-rata try out diatas menujukkan bahwa penggunaan strategi membaca yang efektif sangat berpengaruh sekali dalam membantu siswa mudah menjawab soal-soal UN bahasa Inggris. Berikut strategi membaca yang diajarkan disertai dengan contoh-contoh penerapannya.

\section{Skimming}

Skimming adalah teknik membaca cepat untuk menentukan topik atau pokok pikiran dalam bacaan. Menurut Soedarso (2004), skimming merupakan keterampilan membaca cepat secara sistematis dengan maksud untuk mengambil ide pokok/gagasan utama dari suatu bacaan secara efektif. Dalam strategi skimming ini, siswa hanya perlu membaca sepintas dari teks bacaan untuk mendapatkan isi keseluruhan dari teks tersebut tanpa perlu membaca dengan detail kata perkata. Sehingga, mereka dapat menghemat waktu dalam ujian. 
Contoh soal

The Songkran festival is celebrated in Thailand as the traditional New Year's Day. It is celebrated from 13 to 15 April. It coincides with the New Year of many calendars of South and Southeast Asian countries. It is believed to have been adapted from the Sankranti Hindu festival. It is now observed nationwide even in the far south.

However, the most famous Songkran celebrations are still in the northern city of Chiang mai, where it last for six days and even longer. It has also become a party for foreigners and an additional reason for tourists to visit Thailand. The most obvious celebration of Songkran is the throwing of water to other people. Thais roam the streets with containers of water or water guns. In addition, many Thais will have small bowls cheap beige colored tale and mixed with water which is then smeared on the faces and bodies of random passersby as a blessing for the New Year. City officials close off many sections of the street for the festival.

Besides the throwing of water, people celebrate Songkran by going to a wat (Buddhist monastery) to pray and give food to monks. They also cleanse Buddha images in the household shrines as well a Buddha images at monasteries by gently pouring water mixed with a Thai fragrance over them. It is believed that doing this will bring good luck and prosperity in the New Year. In many cities, such as Chiang Mai, the Buddha imaaes from al of the citv's important monasteries are paraded

What is the main idea of paragraph 2 ?
A. The celebration is longer than a week
B. People come to Thailand for the festival
C. People sell special tale for Sngkran festival
D. The most famous Songkran Celebration is in Chiang mai

Ada beberapa langkah yang yang dapat dilakukan dalam menerapkan skimming dalam menjawab soal. Pertama, siswa harus membaca soal terlebih dahulu. Selanjutnya, siswa bisa langsung menelusuri teks bacaan dengan kecepatan yang tinggi dari setiap paragraf yang dilalui. Jika teks bacaan hanya dalam satu paragraf, siswa hanya perlu memperhatikan kalimat pertama dari paragraf tersebut karena biasanya gagasan utama/ide pokok terletak pada kalimat pertama. Siswa juga harus memperhatikan kalimat-kalimat penjelas setelah kalimat utama dan juga kalimat penutup yang terletak diakhir paragraf. Di sisi lain, jika teks bacaan lebih dari satu paragraf, siswa harus memperhatikan kalimat pertama pada masing-masing paragraf. Jangan lupa juga untuk memperhatikan kalimat penjelas 
dari masing-masing paragraf. Setelah itu, lihat kembali soal, abaikan semua pilihan jawaban yang tidak memiliki hubungan dengan isi teks. Pilihlah jawaban yang benarbenar menggambarkan gagasan utama dalam teks bacaan tersebut.

Untuk menjawab contoh soal diatas, siswa langsung saja membaca paragraf kedua. Perhatikan dengan cermat kalimat pertama dari paragraf dua ini karena umumnya gagasan utama ada pada kalimat pertama. Didalam paragraf ini, di awal kalimat pertama jelas menyebutkan tentang tempat perayaan Songkran yang paling terkenal yaitu di Kota Chiang mai yang juga dijelaskan oleh kalimat pendukung setelahnya. Sehingga, bisa langsung teridentifikasi bahwa paragraf 2 dalam teks bacaan ini membahas tentang "The most famous Songkran Celebration is in Chiang mai."

\section{Scanning}

Scanning adalah teknik membaca untuk mendapatkan sebuah informasi tertentu dalam sebuah bacaan secara cepat dan akurat. Menurut Brown (2007), scanning berhubungan dengan kegiatan mencari informasi yang spesifik seperti angka, tempat, nama, waktu, dan kata kunci lainnya yang ada didalam teks. Strategi ini berguna dalam menjawab pertanyaan yang berkaitan dengan who, what, how long, where, when, how much, how far, dan sebagainya. Contoh penerapan scanning dapat dilihat pada soal dibawah ini.

\section{Drama Club}

The Drama Club will perform a play called "The Magic Carpet". All teachers, parents and students are invited to watch the play. The play will be held on:

Day/date : Monday, December $21^{\text {st }}, 2016$

Time $\quad: 10.00$ a.m.

Venue : School hall

Where should the students register to join the play?
A. At students club
B. In Rudi's office
C. At drama club
D. At school hall

Untuk menjawab soal diatas, siswa dapat mengikuti langkah-langkah scanning diantaranya; (1) baca soal dan cari kata kunci yang ditanyakan soal tersebut; (2) pahami organisasi teks yang diberikan untuk bisa memperkirakan letak jawaban; (3) bacalah baris-baris yang disebutkan dalam soal secara cepat untuk menemukan kata kunci soal; (4) pilihlah jawaban yang menunjukkan baris yang mengandung kata kunci tersebut. 
Untuk soal diatas, siswa bisa langsung melihat kata kunci yang ditanyakan yaitu "where" yang berarti menanyakan tempat. Siswa bisa langsung membaca cepat untuk melihat kata yang menerangkan tentang lokasi atau tempat dalam teks tersebut. Dan akan diperoleh jawaban yang tepatnya adalah yaitu opsi D "in Rudi's office."

\section{Recognizing Text Organization}

Strategi ini merupakan salah satu strategi membaca yang berkaitan dengan pengenalan struktur organisasi yang akan membedakan jenis teks yang satu dan yang lainnya. Dalam menjawab soal berkaitan dengan mengidentifikasi struktur sebuah teks, siswa harus benar-benar paham jenis teks/paragraf dan tata organisasi dari penulisan teks tersebut. Pada jenjang SMP ada beberapa teks yang harus dikuasai siswa seperti narrative text, procedure text, recount text, descriptive text, dan report text.

Contoh soal:

Chameleon Facts

Chameleon is a type of lizard. There are around 160 speciaes of chameleons which can be found mostly on the Madagascar (half of all species live there), in the Africa, southern Europe, south Asia and Sri Lanka. Some chameleon species are endangered due to habitat loss and destruction and because they are sold as pets.

Chameleons have unique eyes, which can move separately from each other and achieve visual field of 180 degrees. This way chameleon can watch in two different directions at the same time and detect objects on the opposite sides. Eyes move rotationally and together provide visual field of 360 degrees.

Chameleons are vary in size. The smallest chameleon is Brookesta micra, which reaches 0,6 inches in length. The biggest chameleon is Furcifer oustaleti, which reaces 30 inches in length.

Chameleons prefer life in the forest and they adapted to move in the trees. Their toes are divided in two groups of two or three toes on each foot,

What is the writer's intention to write the text?
A. To explain how chameleons detect the object
B. To inform about some endangered chameleons
C. To describe chameleon species in general
D. To tell how chaeleons move their bodies 
Untuk menjawab soal diatas, siswa harus memahami masing-masing struktur teks yang telah mereka pelajari di sekolah. Hal ini akan membantu mereka dalam menentukan struktur teks. Seperti soal diatas, jenis teks yang digunakan adalah descriptive text. Descriptive text merupakan jenis teks yang bertujuan untuk memberikan gambaran (sifat, bentuk, ukuran, warna, dsb) dari sesuatu (manusia, benda, tempat) secara detail dan spesifik. Dengan memahami struktur teks descriptive ini, siswa bisa langsung menangkap tujuan yang ingin digambarkan oleh teks diatas yaitu "to describe chameleon species in general" dengan $\mathrm{C}$ sebagai opsi jawaban yang benar.

\section{Interpreting Reference}

Interpreting reference merupakan salah satu strategi membaca untuk menemukan acuan atau sumber rujukan kata ganti yang ada dalam teks. Biasanya dalam soal reference berupa pertanyaan seperti dibawah ini:

a. The pronoun 'they' in line 7 refers to....

b. The word 'it' in line 4 refers to....

c. The pronoun 'she' in line 3 refers to....

Contoh Soal

1. First of all, plug in the cable into the electronic outlet.

2. Then press the 'on' button to yutrn on the machine

3. Open up the cover and put the document face down on the glass surface to enable the censor detect the document

4. If you want to make more copies, you can select numbers on the "Select" button

5. Closed the cover and press "copy" button untuil a flash is passing through the machine

6. One it stops, your copy document is ready in the tray to collect.

(Soal UN bahasa Inggris SMP/Mts tahun 2017)

"Once it stops, ....." (step 6)

The word "it" refers to...
A. The copy button
B. The flash
C. The select button
D. The cover

Untuk menjawab soal tentang kata ganti rujukan ini, siswa bisa melihat beberapa tips berikut ini:

1. Baca dan pahami soal, lalu temukanlah kata benda yang dirujuk oleh kata ganti tersebut. 
2. Kata benda yang dirujuk selalu disebutkan sebelum kata gantinya

3. Carilah kata ganti dalam baris kalimat yang dirujuk atau pada kalimat sebelumnya

4. Bacalah juga kalimat sebelum kata ganti itu

5. Jika kata gantinya berupa "They" merujuk pada kata benda jamak, tapi jika kata gantinya berupa "it" merujuk pada kata benda tunggal.

Untuk menjawab soal diatas, siswa pertama kali harus melihat kalimat dari kata yang dirujuk. Di dalam soal diberi petunjuk dengan baris ke 6 . Dengan membaca baris ke 6 siswa bisa melihat bahwa kata rujukan yang ingin dicari yaitu 'It' yang merujuk pada kata tunggal. Setelah itu, siswa bisa baca kalimat/baris sebelumnya. Dan akan diperoleh jawaban dari rujukan kata "it" adalah "the flash."

Berikut ini foto kegiatan pengabdian masyarakat pada SMP Negeri 4 Kota Solok
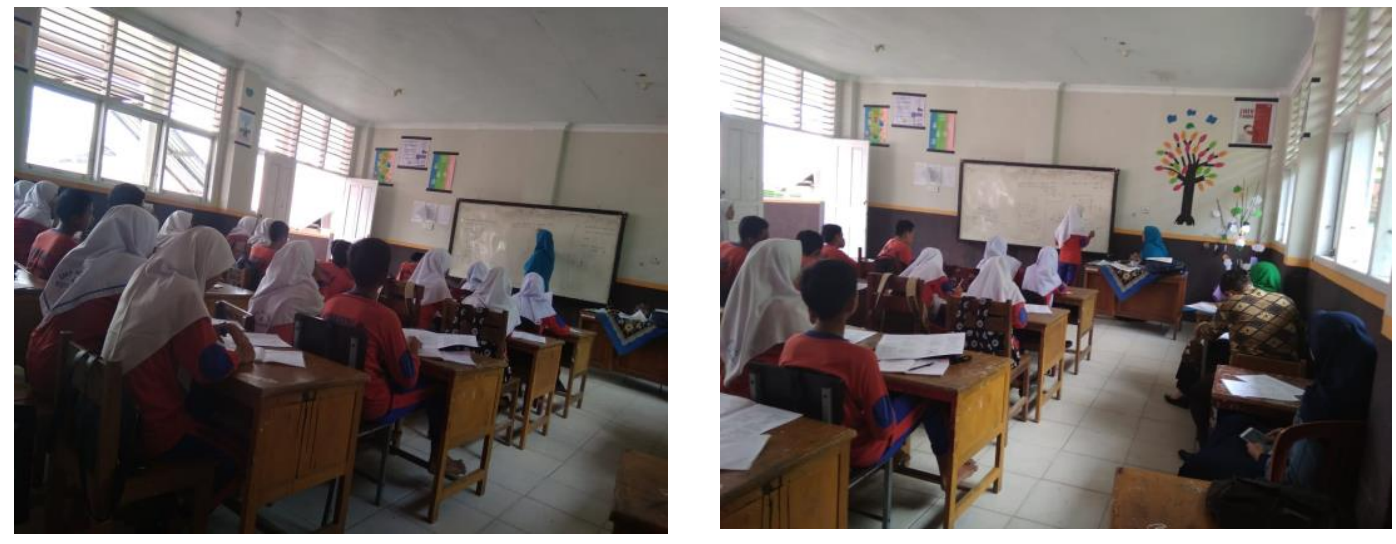

Gambar 1. Penjelasan Tentang Strategi Membaca dalam Menjawab Soal UN Bahasa Inggris

\section{KESIMPULAN}

Berdasarkan hasil dari pengabdian yang telah dilakukan pada siswa kelas IX SMP Negeri 4 Kota Solok, dapat diambil kesimpulan sebagai berikut:

1. Siswa memiliki pengetahuan yang luas tentang strategi menjawab soal Ujian Nasional bahasa Inggris

2. Siswa menjadi lebih bersemangat dan aktif dalam menjawab soal-soal UN bahasa Inggris. Selama proses pelatihan juga, siswa memperlihatkan sikap positif walaupun kegiatan ini hanya berlangsung dua kali pertemuan, dampak yang dihasilkan cukup efektif dalam meningkatkan kemampuan siswa. 
Disamping itu, siswa menjadi termotivasi belajar untuk persiapan menghadapi ujian nasional.

3. Dengan adanya pelatihan tentang penggunaan strategi membaca dalam menjawab soal-soal UN bahasa Inggris, para siswa mendapatkan informasi yang sangat berguna dalam mempersiapkan diri mereka sedini mungkin untuk menghadapi ujian nasional.

\section{SARAN}

Melihat besarnya manfaat kegiatan pengabdian kepada masyarakat ini, maka selanjutnya perlu:

1. diberikan pelatihan yang intensif dan terstruktur bagi siswa kelas IX tentang cara menjawab soal-soal UN bahasa Inggris dengan mudah

2. diharapkan siswa bisa menerapkan strategi membaca yang telah diajarkan dalam pelatihan ini dalam menjawab soal-soal UN nantinya

3. disarankan kepada siswa untuk terus mempersiapkan dirinya dalam menghadapi ujian nasional dengan terus belajar memahami materi dan jenisjenis soal yang diujikan dalam ujian nasional

\section{UCAPAN TERIMA KASIH}

Kami mengucapkan terima kasih kepada Lembaga Penelitian dan Pengabdian Masyarakat (LP3M) Universitas Mahaputra Muhammad Yamin atas dukungan dana yang diberikan untuk pelaksanaan program pengabdian pelatihan strategi membaca bagi siswa kelas IX SMP Negeri 4 Kota Solok tahun akademik 2019/2020 dalam menjawab soal-soal UN bahasa Inggris. Selanjutnya, Kami juga mengucapkan terima kasih kepada SMP Negeri 4 Kota Solok, secara khusus kepada kepala sekolah, guru, staff, dan siswa yang telah berpartisipasi aktif dalam mengikuti kegiatan pelatihan sejak awal hingga akhir dengan baik. Semoga kegiatan pengabdian ini dapat memberikan dampak yang baik terhadap peningkatan kemampuan bahasa Inggris siswa dan kerja sama bisa terus berlanjut dalam bentuk kegiatan lainnya.

\section{DAFTAR PUSTAKA}

Brown, D. H. (2007). Teaching by Principles: An Interactive Approach to Language Pedagogy. White Plains: Pearson Education Company.

Hafis, M.,et al. (2018). Pelatihan strategi belajar bahasa Inggris siswa kelas III SMP Walisongo dalam menghadapi ujian nasional 2018. GERVASI: Jurnal Pengabdian kepada Masyarakat, 2(2), 176-186.

Kisi-Kisi Ujian Nasional Sekolah Menengah Pertama/Madrasah Tsanawiyah Tahun Pelajaran 2018/2019 
Mardapi, D. (2008). Teknik Penyusunan Instrumen Tes dan Nontes. Yogyakarta: Mitra Cendekia.

Mardapi, D., \& Kartowagiran, B. (2009). Dampak ujian nasional. Laporan Hasil Penelitian Jurusan Penelitian dan Evaluasi Pendidikan. Yogyakarta: Universitas Negeri Yogyakarta.

Peraturan Menteri Pendidikan dan Kebudayaan Republik Indonesia Nomor 4 tahun 2018 Tentang Penilaian Hasil Belajar oleh Satuan Pendidikan dan Penilaian Hasil Belajar oleh Pemerintah

Soal UN bahasa Inggris SMP/Mts tahun 2017

Soal UN bahasa Inggris SMP/Mts tahun 2018

Soedarso. (2006). Speed Reading Sistem Membaca Cepat dan Efektif. Jakarta: Gramedia Pustaka Utama. 
